\title{
Badanie relacji między stanem wytężenia a parametrami impedancji niskoczęstotliwościowej
}

\author{
The study of the relationship between the material effort \\ and the low-frequency parameters
}

\section{Streszczenie}

W artykule przedstawiono wyniki badań własnych oraz wybrane dane literaturowe dotyczące identyfikacji stanu wytężenia materiału przy pomocy niskoczęstotliwościowej impedancji elektromagnetycznej. Przedstawiono motywację badań i podstawy teoretyczne metody. Zwrócono uwagę na niejawny, nieliniowy związek istniejący pomiędzy parametrami mechanicznymi i elektromagnetycznymi materiału a stanem jego wytężenia. Omówiono tor pomiarowy używany w badaniach. Omawianą tematykę zobrazowano przykładami. Na podstawie wyników badań wykazano możliwość stosowania taniego mostka LCR do wiarygodnego diagnozowania stanu wytężenia materiału.

Słowa kluczowe: przewodnik; stan wytężenia; NDT; CM; SHM; impedancja

\begin{abstract}
The results of research and selected literature data concerning the identification of the state of material effort with using low-frequency electromagnetic impedance have been presented in the article. Motivation of research and theoretical foundations of the method are presented. Attention has been paid to implicit non-linear relationship between the mechanical and electro-magnetic properties of material and the effort of the state. Measuring circuit used in research has been presented. Discussed topics illustrated samples. Based on the result of studies it demonstrated the possibility of using low-cost LCR bridge to reliably diagnose the state of material effort.
\end{abstract}

Keywords: conductive material; state effort of; NDT; CM; SHM, impedance

\section{Wstęp}

Metody elektromagnetyczne, które są stosowane w badaniach nieniszczących i systemach monitorowania konstrukcji, bazują na pośredniej ocenie właściwości elektrycznych i magnetycznych badanego materiału:

- konduktywności elektrycznej $\sigma=\mathrm{J} / \mathrm{E}$, która odwzorowuje relację między gęstością prądu elektrycznego J w materiale $\mathrm{z}$ natężeniem pola elektrycznego $\mathrm{E}$ powodującego przepływ tego prądu;

- przenikalności elektrycznej $\varepsilon=D / E$, która charakteryzuje zdolność materiału do zmiany indukcji pola elektrycznego D przy zmianie natężenia pola elektrycznego $\mathrm{E}$;

- przenikalności magnetycznej $\mu=\mathrm{B} / \mathrm{H}$, która określa zdolność materiału do zmiany indukcji magnetycznej B przy zmianie natężenia pola magnetycznego $\mathrm{H}$.

Ideę badań elektromagnetycznych mającą na celu kontrolę parametrów fizycznych materiału, niejawnie skorelowanych ze składem chemicznym, strukturą i parametrami mechanicznymi oraz stanem wytężenia i technicznym obiektu [1 $\div 5]$, w sposób poglądowy przedstawiono na rysunku 1 .

W artykule przybliżono zagadnienie identyfikacji symptomów diagnostycznych monitorowania stanu wytężenia materiału przy pomocy niskoczęstotliwościowej spektroskopii impedancji. Szczególnym jej przypadkiem jest defektoskopia metodą prądów wirowych (jedno-, dwu-, wieloczęstotliwościowa) $[1,6]$.

\section{Motywacja}

Bezpieczna eksploatacja maszyn i urządzeń wymaga okresowego wykonywania badań nieniszczących i/lub monitorowania warunków pracy krytycznych elementów. Podczas badań diagnostycznych wymagane jest wysokie prawdopodobieństwo detekcji danego zagadnienia badawczego (ang. Probability of Detection, POD) przy pomocy wybranej metody badawczej, co jest uwarunkowane od:

- znajomości oczekiwanych symptomów diagnostycznych,

- jakości toru pomiarowego,

- algorytmów analizy numerycznej sygnału i ekstrakcji symptomów diagnostycznych,

- poprawności zdefiniowanych kryteriów diagnostycznych,

- umiejętności praktycznych i wiedzy teoretycznej posiadanej przez operatora.

Spełnienie wymagania wysokiego POD w badaniach elektromagnetycznych przekłada się na:

Dr hab. inż. Maciej Roskosz; mgr inż. Krzysztof Fryczowski - Politechnika Śląska Instytut Maszyn i Urządzeń Energetycznych, dr inż. Mirosław Witoś - Instytut Techniczny Wojsk Lotniczych Zakład Informatycznego Wsparcia Logistyk.

Autor korespondencyjny/Corresponding author: maciej.roskosz@polsl.pl 
- właściwy dobór pasma częstotliwości sygnału testującego, w których będą występowały wyraźne zmiany charakterystyk parametrów elektrycznych i magnetycznych materiału (w ogólnym przypadku tensorów zespolonych drugiego rzędu):

$\sigma(\omega)=\sigma_{1}(\omega)+j \sigma_{2}(\omega), \varepsilon(\omega)=\varepsilon_{1}(\omega)+j \varepsilon_{2}(\omega), \mu(\omega)=\mu_{1}(\omega)+j \mu_{2}(\omega)$

- dobór odpowiedniej metody i aparatury pomiarowej (w tym typu sond) oraz używanie zweryfikowanych algorytmów analizy danych przez przeszkolonego użytkownika.

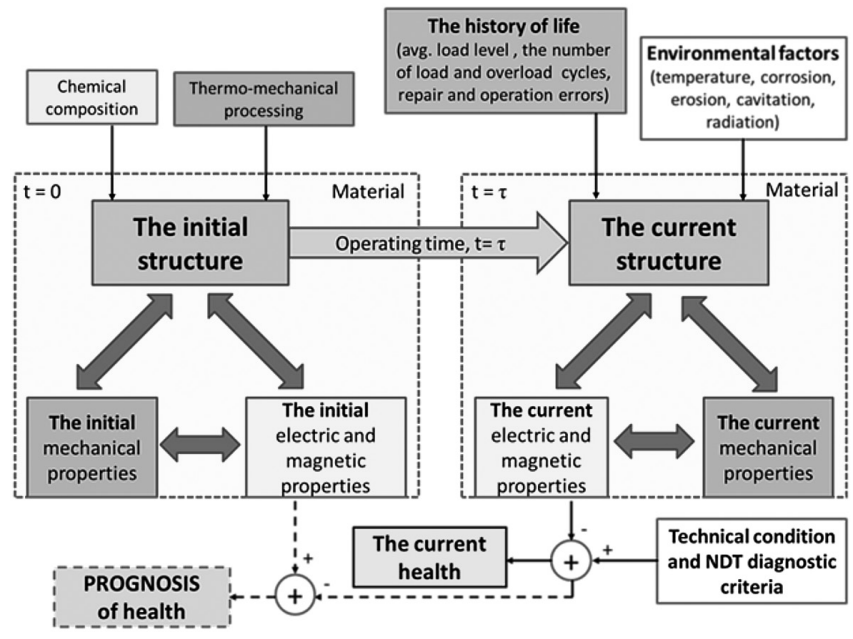

Rys. 1. Idea badań elektromagnetycznych materiału nowego i z eksploatacji [5]

Fig. 1. The idea of electromagnetic testing of the material (new and in-service) [5]

Charakterystyki częstotliwościowe $\sigma(\omega), \quad \varepsilon(\omega), \quad \mu(\omega)$, i są różne dla różnych materiałów konstrukcyjnych, typu mikrostruktury i obróbki cieplno-mechanicznej, co jest świadomie wykorzystywane w systemach automatycznej kontroli jakości produkcji bazujących m.in. na metodzie wieloczęstotliwościowych prądów wirowych (PMFT, ang. Preventive Multi-Frequency Test) i analizie harmonicznych [1,6]. Dobór częstotliwości testujących w metodzie PMFT - tablica I, uwzględnia właściwości materiału (paramagnetyk, miękki i twardy ferromagnetyk, itp.), cel badań i parametry metrologiczne toru pomiarowego.

Charakterystyki częstotliwościowe parametrów fizycznych materiału ulegają również zmianie pod wpływem:

- degradacji eksploatacyjnej (wzrostu gęstości dyslokacji, zmian ilościowych fazy podstawowej struktury, wydzieleniu węglików i pojawieniu się mikro- i makropęknięć) [12,13] - rysunek 2,

- zmian stanu wytężenia materiału i parametrów warstwy wierzchniej $[7 \div 9]$ i rysunek 2 ,

- zmian temperatury materiału,

- zmian natężenia zewnętrznego pola magnetycznego (materiały ferromagnetyczne).

- co jest wykorzystywane w badaniach nieniszczących (NDT), systemach monitorowania parametrów pracy (CM) i systemach monitorowania stanu technicznego (SHM).

Dane z tabeli I oraz informacje zamieszczone w różnych ogólnodostępnych raportach i artykułach, bez dodatkowej informacji o parametrach cewki i dopasowaniu jej impedancji do parametrów fizycznych badanego obiektu, oraz ogólna wiedza z elektromagnetyzmu są niewystarczająca do opracowania wiarygodnych kryteriów diagnostycznych. Wymagana jest weryfikacja rozproszonej wiedzy i symptomów diagnostycznych.

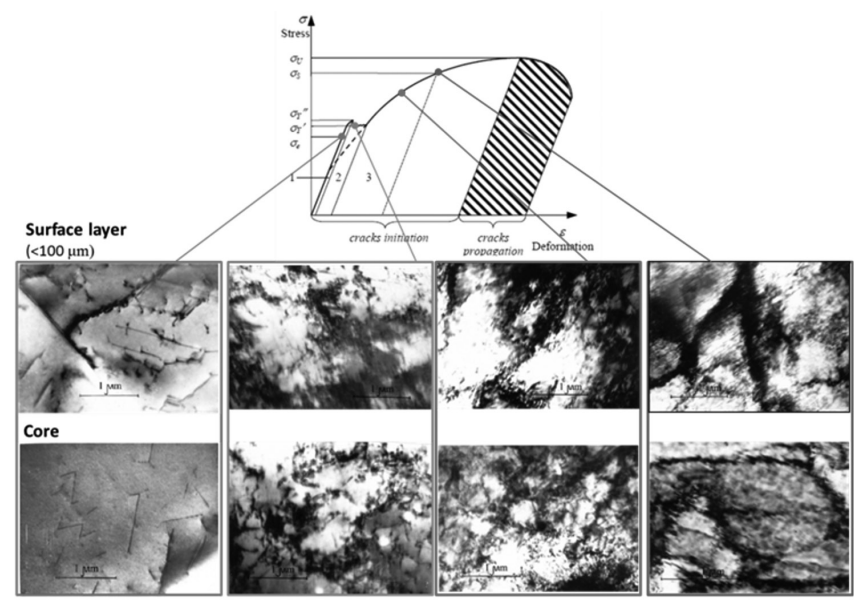

Rys. 2. Różnica gęstości dyslokacji w warstwie wierzchniej i rdzeniu próbki podczas quasi-statycznego rozciągania [10]

Fig. 2. The difference in dislocation density in the surface layer and the core of sample during quasi-static tension [10]

\section{Podstawy teoretyczne metody impedancji}

Właściwości elektryczne i magnetyczne materiałów przewodzących prąd elektryczny są modelowane jako rzeczywisty induktor - obwód równoległy LCR o 5 elementach $\left(R_{p}, C\right.$, $\left.R_{c}, L, R_{L}\right)$ i impedancji $Z_{m}$ [5]. Między parametrami elektromagnetycznymi badanego materiału i elementami zastępczego

Tablica I. Typowe częstotliwości sygnału testującego stosowane w metodzie PMFT do kontroli jakości materiału i gotowych wyrobów [1] Table I. The typical frequency of the test signal used in PMFT method to control the quality of the material and finished products [1]

\begin{tabular}{|c|c|c|c|c|c|c|c|c|c|}
\hline $\begin{array}{c}\text { Zagadnienie } \\
\text { badawcze }\end{array}$ & Pasmo $[\mathrm{Hz}]$ & $\begin{array}{c}\mathbf{F}_{1} \\
{[\mathrm{~Hz}]}\end{array}$ & $\begin{array}{c}\mathbf{F}_{2} \\
{[\mathrm{~Hz}]}\end{array}$ & $\begin{array}{c}\mathbf{F}_{3} \\
{[\mathrm{~Hz}]}\end{array}$ & $\begin{array}{c}\mathbf{F}_{4} \\
{[\mathrm{~Hz}]}\end{array}$ & $\begin{array}{c}\mathbf{F}_{5} \\
{[\mathrm{~Hz}]}\end{array}$ & $\begin{array}{c}\mathbf{F}_{6} \\
{[\mathrm{~Hz}]}\end{array}$ & $\begin{array}{c}\mathbf{F}_{7} \\
{[\mathrm{~Hz}]}\end{array}$ & $\begin{array}{c}\mathbf{F}_{8} \\
{[\mathrm{~Hz}]}\end{array}$ \\
\hline $\begin{array}{c}\text { Materiały } \\
\text { ferromagnetyczny }\end{array}$ & $25-100000$ & 25 & 160 & 800 & 2500 & 6400 & 16000 & 40000 & 100000 \\
\hline $\begin{array}{c}\text { Stopy } \\
\text { austenityczne }\end{array}$ & $100-100000$ & 100 & 230 & 860 & 2500 & 6400 & 16000 & 40000 & 100000 \\
\hline $\begin{array}{c}\text { Stopy } \\
\text { nieferromagne- } \\
\text { tyczne }\end{array}$ & $100-100000$ & 100 & 240 & 600 & 1500 & 5000 & 15000 & 40000 & 100000 \\
\hline $\begin{array}{c}\text { Materiały } \\
\text { twarde }\end{array}$ & $50-60000$ & 50 & 120 & 430 & 860 & 3200 & 12000 & 30000 & 60000 \\
\hline $\begin{array}{c}\text { Odpuszczanie } \\
\text { Odpen }\end{array}$ & $25-25000$ & 25 & 80 & 250 & 630 & 1600 & 4000 & 10000 & 25000 \\
\hline $\begin{array}{c}\text { Hartowanie } \\
\text { powierzchniowe }\end{array}$ & $100-25000$ & 100 & 250 & 500 & 1000 & 2500 & 5000 & 11000 & 25000 \\
\hline
\end{tabular}


obwodu LCR zachodzą związki: $\sigma \propto R^{-1}, \varepsilon \propto C, \mu \propto L$. Bieżące parametry materiału i stan jego wytężenia są odwzorowane w charakterystyce częstotliwościowej impedancji $Z_{m}(\omega)$, którą można kontrolować bezdotykowo przy pomocy cewki zasilanej napięciem zmiennym $u(\omega, t)$. Cewka, przez którą płynie prąd elektryczny $i(\omega, t)$, jest źródłem lokalnego strumienia magnetycznego $\Phi(\omega, t)=\Phi_{g}(\omega, t)+\Phi_{S}(\omega, t)$ (strumienia głównego i strumienia rozproszenia) i pola magnetycznego $B(\omega, t)$. Gdy cewka znajduje się w pobliżu badanego elementu i nie jest galwanicznie z nim połączona, to główny strumień magnetyczny $\Phi_{g}(\omega, t)$ przenika przez badany materiał indukując $w$ materiale siłę elektromotoryczną $e(\omega, t)$ i prądy wirowe $i_{E C}(t)$. Ich widmo i rozkład przestrzenny są zależne od:

- właściwości elektrycznych i magnetycznych badanego materiału, w tym impedancji powierzchniowej i impedancji warstwy wierzchniej materiału - parametrów silnie zmieniających się pod wpływem naprężeń;

- parametrów sprzęgnięcia cewki z badanym elementem - indukcyjności wzajemnej $M$,

- częstotliwości sygnału testującego.

Prądy wirowe zmieniają rozkład dotychczasowego pola magnetycznego w materiale i w jego pobliżu, co można wykryć przy pomocy czułego magnetometru lub pomiaru zmian impedancji cewki testującej $\Delta Z_{s}=Z_{s, m}-Z_{s, 0}$ - zmian impedancji obwodu pierwotnego wirtualnego transformatora [2,3], w którym dodano indukcyjność $\Delta L$ i rezystancję $\Delta R$ odwzorowującą:

- nieznane parametry badanego materiału (obwodu wtórnego transformatora),

- sprzęgnięcia magnetyczne (indukcyjne) sondy z badanym materiałem.

Dla danej częstotliwości testującej $f$ i jednorodnego materiału, gęstość prądów wirowych na głębokości $x$ od powierzchni badanego elementu maleje wykładniczo [2], co opisuje relacja

$$
J_{x}=J_{0} e^{-x\left(\pi f \mu_{0} \mu_{r} \sigma\right)^{0.5}}
$$

gdzie $J_{0}$ jest gęstością prądów powierzchniowych, $\mu_{0}$ jest przenikalnością magnetyczną próżni (wartość skalarna $\mu_{0}=4 \cdot \pi \cdot 10^{-7}[\mathrm{H} / \mathrm{m}]=12.566370614 \ldots[\mathrm{Vs} / \mathrm{A}], \quad \mu_{r}$ jest względna przenikalnością magnetyczną materiału, $\sigma$ jest konduktywnością elektryczną materiału [S/m].

Dla materiałów niejednorodnych, np. rdzenia z warstwą wierzchnią wytworzoną przez naprężenia o większej gęstości dyslokacji - rysunek 2, rozkład gęstości prądów wirowych $J_{x}$ będzie odbiegał od rozkładu teoretycznego opisanego zależnością (2). Poziom niejednorodności właściwości elektrycznych i magnetycznych materiału można identyfikować na podstawie lokalnych zmian charakterystyk $\sigma(\omega)$, $\varepsilon(\omega), \mu(\omega)$, i względem charakterystyk wzorcowych dla danego materiału, wykonując pomiary dla różnych częstotliwości sygnału testującego. Powyższe spostrzeżenie zostało wykorzystane przez Autorów do monitorowania naprężeń.

Głębokość wnikania prądów wirowych do materiału określa zakres stosowania metody impedancji niskoczęstotliwościowej i wykładnię interpretacji wyników pomiarów. Standardowa głębokość penetracji $\delta$ jednorodnego materiału przez prądy wirowe jest zdefiniowana jako punkt, w którym gęstość prądu elektrycznego zmniejsza się o współczynnik $1 / \mathrm{e} \approx 36,8 \%$, co opisuje relacja (3). Czym mniejsza jest częstotliwość sygnału testującego tym głębsza jest penetracja materiału przez prądy wirowe. Praktyczna głębokość badania materiału z wykorzystaniem prądów wirowych nie przekracza $3 \delta$.

$$
\delta=\frac{1}{\sqrt{\pi f \mu_{0} \mu_{r} \sigma}}
$$

\section{Impedancja elektryczna}

Bieżące parametry sondy pomiarowej (obwodu pierwotnego wirtualnego transformatora zawierającego dwie równoległe gałęzie: cewki o indukcyjności $L$ i rezystancji $R$ oraz pojemości toru pomiarowego $C$ ) są odwzorowane przez impedancję elektryczną opisana relacją:

$$
Z(\omega)=\frac{u(\omega, t)}{i(\omega, t)}=|Z| e^{-j \varphi}=R+j X
$$

gdzie $|Z|=|Z|(\omega)$ jest modułem impedancji $\left(|Z|=\sqrt{\left(R^{2}+X^{2}\right)}\right.$; $\varphi=\varphi(\omega)$ jest przesunięciem fazowym między napięciem a natężeniem prądu elektrycznego; $R=R(\omega)$ jest rezystancją (oporem czynnym), która odpowiada za prąd płynący w fazie z napięciem i moc czynną; $X=X(\omega)$ jest reaktancją (oporem biernym), która odpowiada za prąd przesunięty względem napięcia o $\pm 90^{\circ}$ i moc bierną; $\omega=2 \pi f$ jest częstością kołową; $j$ jest jednostką urojoną liczby zespolonej $\left(j^{2}=-1\right)$.

\section{Współczynnik sprzężenia}

Sprzężenie magnetyczne sondy z badanym materiałem (układ dwóch cewek sprzężonych indukcyjnie) jest opisany przez trzy główne parametry:

- indukcyjności własne obydwu cewek $\left(L_{1}\right.$ - o znanej wartości, $L_{2}$ - identyfikowanej);

- indukcyjności wzajemnej $M$.

Indukcyjność wzajemną cewki sondy z wirtualną cewką badanego materiału $M_{12}$ nazywamy stosunek strumienia głównego wytworzonego w cewce sondy i skojarzonego z nieznaną indukcyjnością badanego materiału do prądu płynącego w cewce sondy.

$$
M_{12}=N_{2} \frac{\Phi_{1 g}}{i_{1}}
$$

Analogicznie dla wirtualnej cewki badanego materiału

$$
M_{21}=N_{1} \frac{\Phi_{2 g}}{i_{2}}
$$

Z podstawowych praw elektromagnetyzmu wynika, że dla ośrodka izotropowego (sprzęgniecie cewki z badanym materiałem poprzez powietrze) zachodzi relacja

$$
M=M_{12}=M_{21}=\sqrt{L_{1 g} \cdot L_{2 g}}
$$

Indukcyjność wzajemna jest średnią geometryczną obu indukcyjności głównych.

Wyznaczenie indukcyjności wzajemnej $M$ umożliwia określenie wartości współczynnik sprzężenia $k$ sondy z badanym materiałem. Zgodnie z definicją, współczynnik sprzężenia

$$
k=\frac{M}{\sqrt{L_{1} L_{2}}}=\sqrt{\frac{L_{1 g} L_{2 g}}{L_{1} L_{2}}}
$$

jest wielkością bezwymiarową w zakresie $k \in\langle 0 ; 1\rangle$, której wartość zależy od kształtu geometrycznego cewek (sondy i wirtualnej cewki badanego obiektu), ich liczby zwojów (dla materiału: impedancji powierzchniowej i jednorodności elektromagnetycznej), a ponadto od wzajemnego usytuowania sondy względem powierzchni badanego obiektu, które ma wpływ na podział całkowitego strumienia magnetycznego na strumień główny i strumień rozproszenia. Dla cewki bez wpływu badanego materiału $k=0$.

\section{Impedancja sondy bez i z wpływem badanego materiału}

Impedancja cewki powietrznej bez oddziaływania badanego materiału i pojemności toru pomiarowego jest opisana relacją:

$$
Z_{0}=R_{0}+j \omega L_{0}
$$


Impedancja cewki powietrznej z oddziaływaniem badanego materiału jest opisana relacją:

$$
\begin{aligned}
& Z_{e q}=Z_{0}+\frac{\omega^{2} M^{2}}{R_{e}+j \omega L_{e}}=\left(R_{0}+\frac{\omega^{2} M^{2}}{R_{e}{ }^{2}+\left(\omega L_{e}\right)^{2}} R_{e}\right)+ \\
&+j \omega\left(L_{0}-\frac{\omega^{2} M^{2}}{R_{e}{ }^{2}+\left(\omega L_{e}\right)^{2}} L_{e}\right)
\end{aligned}
$$

gdzie $R_{\mathrm{e}} \mathrm{i} L_{\mathrm{e}}$ są ekwiwalentną rezystancją i indukcyjnością pętli prądów wirowych na powierzchni badanego materiału. Równanie (10) po uwzględnieniu zależności (8) można przekształcić do postaci:

$$
Z_{e q}=\left(R_{0}+\frac{R_{e} \frac{L_{0}}{L_{e}} k^{2}}{1+\left(\frac{R_{e}}{\omega L_{e}}\right)^{2}}\right)+j \omega L_{0}\left(1-\frac{k^{2}}{1+\left(\frac{R_{e}}{\omega L_{e}}\right)^{2}}\right)
$$

Gdy częstotliwość sygnału testującego jest na tyle wysoka, że dla badanego materiału spełniony jest warunek $R_{e}<<\omega L_{e}$, to impedancję z równania (11) można zapisać w postaci uproszczonej:

$Z_{e q} \approx\left(R_{0}+R_{e} \frac{L_{0}}{L_{e}} k^{2}\right)+j \omega L_{0}\left(1-k^{2}\right)$

Dla pomiarów wysokoczęstotliwościowych rezystancja i indukcyjność cewki z oddziaływaniem badanego materiału są opisane relacjami:

$$
R_{e q} \approx\left(R_{0}+R_{e} \frac{L_{0}}{L_{e}} k^{2}\right) \quad L_{e q} \approx L_{0}\left(1-k^{2}\right)
$$

z których wynika:

- potrzeba optymalizacji indukcyjności cewki do przenikalności magnetycznej badanego materiału i dominujący wpływ współczynnika sprzężenia na zmiany rezystancji $R_{\text {eq; }}$;

- pomijalny wpływ konduktywności badanego materiału i dominujący wpływ współczynnika sprzężenia na zmiany indukcyjności $L_{e q}$.

Jeżeli współczynnik sprzężenia $k$ będzie ulegać zmianie pod wpływem nieznanych naprężeń czy zmiany wymiarów próbki (współczynnika wypełnienia cewki podczas odkształceń plastycznych), to zmianie ulegać będą równocześnie $R_{e q} i L_{e q}$.

Dla pomiarów niskoczęstotliwościowych, dla których obowiązuje relacja (11), istnieje dodatkowy nieliniowy wpływ konduktywności i przenikalności magnetycznej materiału na składową rzeczywistą i urojoną mierzonej impedancji.

\section{Badania eksperymentalne}

W celu wyznaczenia rzeczywistych możliwości monitorowania stanu wytężenia elementu metodą niskoczęstotliwościowej impedancji wykonano badania laboratoryjne. W badaniach stosowano:

- walcową cewkę powietrzną o indukcyjności $4.246 \mathrm{mH}$ i rezystancji $10.460 \Omega$ dla $\mathrm{f}=100 \mathrm{~Hz}$;

- podręczny automatyczny mostek LCR typ DT-9935 firmy CEM, z wymuszeniem sinusoidalnym i częstotliwościami testującymi: 100 Hz, 120 Hz, 1 kHz, 10 kHz, 100 kHz;

- moduł ewaluacyjny z precyzyjnym przetwornikiem impedancji AD5933EVM firmy Analog Device, który umożliwia automatyczny pomiar impedancji w paśmie od $0.1 \mathrm{~Hz}$ do 100 kHz z klasą dokładności nie gorszą niż 0.2.
Autorzy zweryfikowali poprawność stosowanej metodologii badawczej i jakość uzyskiwanych wyników przy pomocy laboratoryjnego mostka LCR typ IM3532-50 firmy Hioki, zapewniającego klasą dokładności nie gorszą niż 0.08 [5,9].

\section{Eksperyment czynny}

Badania laboratoryjne wykonano na próbkach walcowych o średnicy $4 \mathrm{~mm}$, o stabilnej strukturze austenitycznej, wykonanych ze stopu niklowo-chromowego - tablica II, na których zamontowana była cewka pomiarowa. Próbki były rozciągane na maszynie zmęczeniowej sterowanej komputerowo. Podczas próby schodkowej próbka znajdowała się cały czas pod obciążeniem, którego wartość była zwiększana skokowo co $50 \mathrm{MPa}$. Dla kolejnych poziomów obciążenia wykonano pomiary impedancji dla 5 częstotliwości testujących. $\mathrm{Na}$ rysunku 3 zobrazowano strukturę toru pomiarowego i wyznaczoną krzywą rozciągania materiału. a)

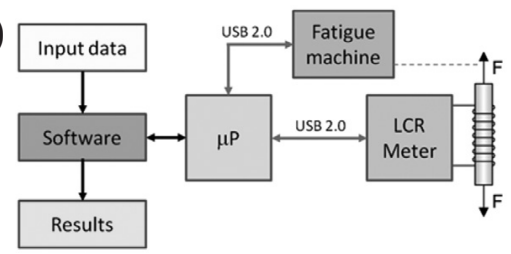

b) ${ }^{800}\left[\mathrm{~F}_{\mathrm{MPa}}\right] \quad \mathrm{Rm}_{\mathrm{m}}=32 \mathrm{MP \textrm {Pa }}$

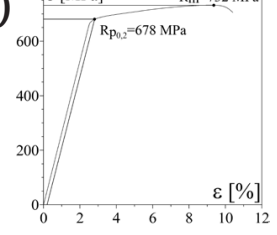

Rys. 3. Zobrazowano: a) schemat blokowo toru pomiarowego; b) krzywą rozciągania badanego materiału - rdzenia elektrody BÖHLER FOX NIBAS 70/20

Fig. 3. Showing: a) schematic diagram of measurement; b) stressstrain curve of the tested material - core of BÖHLER FOX NIBAS $70 / 20$ welding electrode

\section{Wyniki badań}

Wyniki pomiarów poddano analizie numerycznej $z$ uwzględnieniem danych referencyjnych wykonanych dla pustej cewki $(k=0)$ oraz cewki z badanym materiałem przy zerowym obciążeniu - tablica III. Przykładowe charakterystyki wpływu naprężeń badanego materiału na mierzone parametry cewki przedstawiono na rysunku 4.

a)
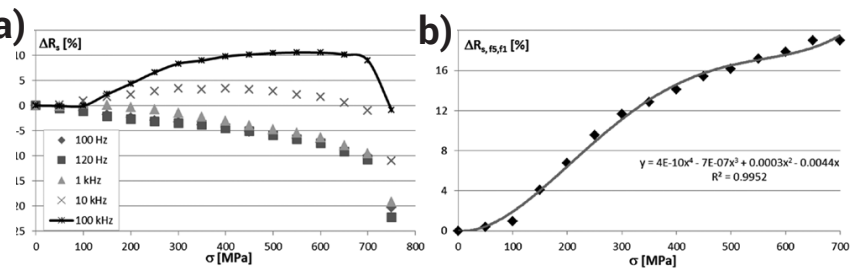

c)

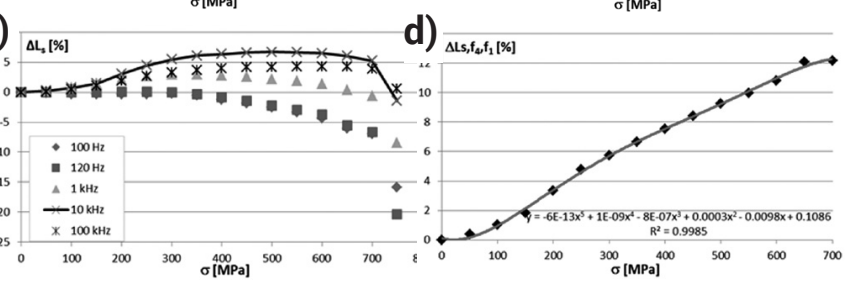

Rys. 4. Zobrazowano wpływ naprężeń rozciągających próbkę na względną zmianę parametrów sondy: a) rezystancji; b) różnicy rezystancji dla $\mathrm{f}_{1}=100 \mathrm{~Hz} \mathrm{i} \mathrm{f}_{5}=100 \mathrm{kHz}$; ) indukcyjności; d) różnicy indukcyjności dla $\mathrm{f}_{1}=100 \mathrm{~Hz}$ i $\mathrm{f}_{4}=10 \mathrm{kHz}$

Fig. 4. Illustrated the effect of tensile stress on the sample relative change in the probe parameters: a) the resistance; b) the difference of resistance for $f_{1}=100 \mathrm{~Hz}$ and $f_{5}=100 \mathrm{kHz} ; c$ ) the inductance; d) the difference of inductance for $f_{1}=100 \mathrm{~Hz}$ and $f_{4}=10 \mathrm{kHz}$

Tablica II. Skład chemiczny badanego materiału (dane katalogowe) [11]

Table II. The chemical composition of the test material (catalog data) [11]

\begin{tabular}{|c|c|c|c|c|c|c|c|c|c|c|}
\hline Skład & C & Si & Mn & Cr & Ni & Mo & Ti & Nb & Co & Fe \\
\hline Wagowo \% & 0.04 & 0.4 & 5.0 & 19.0 & 67.0 & 1.5 & 0.5 & 2.0 & 0.08 & 3.0 \\
\hline
\end{tabular}


Dostrzega się, że wraz z zwiększaniem poziomu naprężeń rozciągających zmienia się rezystancja i indukcyjność cewki sprzęgniętej magnetycznie z badanym materiałem paramagnetycznym, przy czym wartość i trend zmian są zależne od częstotliwości testującej. W zakresie odkształceń sprężystych wartości $\Delta R_{S}$ i $\Delta L_{S}$ maleją dla częstotliwości $100 \mathrm{~Hz}$ i $120 \mathrm{~Hz}$, natomiast dla $1 \mathrm{kHz}, 10 \mathrm{kHz}$ i $100 \mathrm{kHz}$ rosną. W efekcie wzrasta różnica rezystancji i indukcyjności wyznaczona dla różnych częstotliwości testujących, ujawniając narastającą niejednorodność elektromagnetyczną warstwy wierzchniej i rdzenia próbki (szybszy wzrost gę- stości dyslokacji w warstwie wierzchniej). Dla stosowanej cewki maksymalne wartości $\Delta R_{s}\left(f_{\mathrm{i}}, f_{\mathrm{j}}\right)$ są obserwowane dla $100 \mathrm{~Hz}$ i $100 \mathrm{kHz}$, natomiast maksymalne wartości $\Delta L_{s}\left(f_{\mathrm{i}}, f_{\mathrm{j}}\right)$ dla $100 \mathrm{~Hz}$ i $10 \mathrm{kHz}$. W analizie nie uwzględniono zmiany współczynnika wypełnienia cewki spowodowanej odkształceniem plastycznym próbki, mającego wpływ na otrzymywane wyniki pomiarów. Wyniki pomiarów dla stopu paramagnetycznego były powtarzalne, a oszacowana dokładność pomiaru naprężeń była nie gorsza od $2 \%$ dla danych pomiarowych uzyskanych przy pomocy taniego podręcznego mostkiem LCR z klasą dokładności 2.5.

Tablica III. Typowe częstotliwości sygnału testującego stosowane w metodzie PMFT do kontroli jakości materiału i gotowych wyrobów [1] Table III. The typical frequency of the test signal used in PMFT method to control the quality of the material and finished products [1]

\begin{tabular}{|c|c|c|c|c|c|c|c|c|}
\hline \multirow[t]{2}{*}{$\begin{array}{l}\text { Częstotli- } \\
\text { wość }\end{array}$} & \multicolumn{4}{|c|}{$\begin{array}{l}\text { Cewka bez rdzenia } \\
\text { (drut } \mathrm{Cu}, \mathrm{d}_{\text {in }}=4.0 \mathrm{~mm} \text { ) }\end{array}$} & \multicolumn{4}{|c|}{$\begin{array}{c}\text { Cewka z rdzeniem } \\
\text { (DUT: stop Ni-Cr, I = } 150 \mathrm{~mm}, \mathrm{~d}=4.0 \mathrm{~mm}, \\
\sigma=0 \mathrm{MPa} \text {-próbka zamontowana } \mathrm{w} \text { uchwytach maszyny) }\end{array}$} \\
\hline & $\mathbf{R}_{\mathrm{s} 0}$ & $\mathrm{~L}_{\mathrm{s} 0}$ & $\left|Z_{0}\right|$ & $\varphi_{0}$ & $\mathbf{R}$ & $\mathbf{L}$ & $|\mathrm{Z}|$ & $\Phi$ \\
\hline $\mathrm{Hz}$ & $\mathbf{\Omega}$ & $\mathrm{mH}$ & $\Omega$ & Rad & $\mathbf{\Omega}$ & $\mathrm{mH}$ & $\Omega$ & rad \\
\hline 100 & 10.460 & 4.246 & 10.795 & 0.250 & 16.260 & 36.630 & 28.180 & 0.956 \\
\hline 120 & 10.460 & 4.226 & 10.935 & 0.296 & 17.770 & 35.660 & 32.229 & 0.987 \\
\hline 1000 & 10.487 & 4.237 & 28.613 & 1.196 & 68.500 & 19.020 & 137.229 & 1.050 \\
\hline 10000 & 12.498 & 4.237 & 266.512 & 1.524 & 282.100 & 9.368 & 652.718 & 1.124 \\
\hline 100000 & 245.80 & 4.592 & 2895.69 & 1.486 & 1410.6 & 5.916 & 3975.785 & 1.208 \\
\hline
\end{tabular}

\section{Wnioski}

Wykazano eksperymentalnie, że pomiary niskoczęstotliwościowej impedancji elektrycznej cewki sprzęgniętej magnetycznie z badanym materiałem paramagnetycznym umożliwiają wiarygodne monitorowanie stanu jego wytężenia w zakresie odkształceń sprężystych. W analizowanym przypadku nie uwzględniono wpływu modyfikacji współczynnika sprzężenia $k$ spowodowanego zmianą przekroju próbki na wyniki pomiarów. Wpływ ten zostanie przeanalizowany w zaplanowanych pracach badawczych.

Różnicowe charakterystyki wpływu naprężeń na parametry impedancji elektrycznej sondy są skorelowane z niejednorodnością parametrów elektrycznych i magnetycznych warstwy wierzchniej materiału i rdzenia.

Pomiar impedancji elektrycznej sondy wykonany dla kilku częstotliwości minimalizuje negatywny wpływ sprzęgania sondy z badanym materiałem (ang. lift-off) i ułatwia interpretację wyników.

Poprzez aproksymowanie wyników uzyskanych dla 5 częstotliwości z podręcznego mostka LCR można również wyznaczyć optymalne częstotliwości do monitorowania stanu wytężenia materiału, nie mierzone bezpośrednio.

\section{Literatura}

[1] http://www.ibgndt.com.

[2] C.V. Dodd et al.; "Some eddy-current problems and their integral solutions"; ORNL-4384 raport for U.S. Atomic Energy Commission, Oak Ridge, Tennessee, 1969.

[3] Z. H. Żurek, P. Duka; „RLC circuits for material testing and NDT” KOMEL, 2014.

[4] B. A. Abu-Nabah et al.; „Eddy current residual stress profiling in surfacetreated engine alloys"; Nondestructive Testing and Evaluation, Vol. 24, Nos. 1-2, s. 209-232, 2009.

[5] Z. H. Żurek, M. Witoś; "Diagnostics of Degradative Changes in Paramagnetic Alloys with the Use of Low Frequency Impedance Spectroscopy"; 7th International Symposium on NDT in Aerospace, 2015.

[6] J. Gao, M. Pan, F. Luo; „Defect Identification and Classification of MultiFrequency Eddy Current Test Based on Spectrum Method"; IEEE International Conference on Information and Automation, 2010.

[7] W. R. Junker, W. G. Clark Jr.; „Eddy current characterization of applied and residual stresses"; Review of Progress in Quantitative Nondestructive Evaluation, 2B ed. Thompson and Chimenti. Plenum Press, New York, s. $1269-1286,1983$.
[8] Ji-Gou Liu, Wolf-Jürgen Becker; "Force and Stress Measurements with Eddy Current Sensors", The 10. International Sensor fairs and Conference, May 8-10, Nuremberg, Germany, vol. II, s. 23-28, 2001.

[9] K. Fryczowski, M. Roskosz, Z. H. Żurek; „Preliminary Studies on Impact of Tensile Loads on the Parameters of the RLC Circuit"; 44th National conference NDT, 2015; Welding Technology Review, 2015, 87, s. 45-49.

[10] J. Vilysa, V. Kvedarasb; „Dislocation Structure of Near Surface Layers of Deformed Low-carbon Steel"; 15th Int. Metallurgical \& Material Conference METAL 2006.

[11] „Welding Guide. Technical Handbook of BÖHLER WELDING Products", Böhler Welding, 2009.

[12] Krysztofik J., Kukla D., So-cha G.:Ocena stopnia uszkodzenia stopu Inconel 718 z zastosowaniem prądów wirowych, Przegląd Spawalnictwa, Vol 87, No 12 (2015).

[13] Kukla D., Grzywna P., Karczewski R.: Ocena rozwoju uszkodzenia zmęczeniowego na podstawie zmian odkształcenia i parametrów prądowirowych w kolejnych cyklach obciążenia, Przegląd Spawalnictwa, Vol 86, No 5 (2014). 